редкол. : Т. І. Сущенко (гол. ред.) [та ін.]. - Запоріжжя, 2012. - Вип. 79 (26). - С. $137-$ 144. 5. Драч I. I. Теоретичні і методичні засади управління формуванням професійної компетентності магістрантів педагогіки вищої школи : дис. ... д-ра пед. наук : 13.00 .06 / I. І. Драч. - К., 2008. - 485 с. б. Сльникова Г. В. Наукові основи розвитку управління загальною середньою освітою в регіоні : дис. ... д-ра пед. наук : 13.00.01/ Г. В. Сльникова. - Луганськ, 2005. - 446 с. 7. Закон України «Про вищу освіту» [Електронний ресурс]. - Режим доступу: http://zakon.rada.gov.ua 8. Кремень В. Г. Філософія управління : підруч. для студ. вищ. навч. закладів / В. Г. Кремень, С. М. Пазиніч, О. С. Пономарьов. - К. : Знання України, 2007. - 360 с. 9. Маслов В. І. Наукові основи та функції процесу управління загальноосвітніми навчальними закладами : навч. посіб. / В. І. Маслов. - Тернопіль: Астон, 2007. - 150 с. 10. Національна доктрина розвитку освіти // Освіта України. - 2002. - № 33. - С. 4-6. 11. Олійник В. В. Наукові основи управління підвищення кваліфікації педагогічних працівників профтехосвіти : [монографія] / В. В. Олійник. - К. : Міленіум, 2003. 594 с. 12. Указ Президента України від 25 червня 2013 р. № 344/2013 «Про Національну стратегію розвитку освіти в Україні на період до 2021 р.» [Електронний pecypc].- Режим доступу: http://www.president.gov.ua/ru/documents/15828.html 13. Drach I. Methodology for managing a professional competence formation of future teachers in higher education / I. Drach // Europian Applied Sciences, Stuttgart, Germany. 2012. - № 1. - P. 138-140.

УДК 378. 147: 811. 111

Світлана Дуброва

\title{
ПРОФЕСІЙНА ПІДГОТОВКА МАЙБУТНІХ УЧИТЕЛІВ ІНОЗЕМНИХ МОВ ДО ФОРМУВАННЯ КОМУНІКАТИВНОЇ КОМПЕТЕНЦЇ̈ УЧНІВ ОСНОВНОЇ ШКОЛИ: ПРОГРАМА, МЕТОДИКА ТА РЕЗУЛЬТАТИ ЕКСПЕРИМЕНТАЛЬНОГО ДОСЛІДЖЕННЯ
}

Дуброва С. В. Професійна підготовка майбутніх учителів іноземних мов до формування комунікативної компетенції учнів основної школи: програма, методика та результати експериментального дослідження.

У статті висвітлено мету, суть, програму та методику експериментального дослідження, представлено його результати - динаміку та рівні розвитку когнітивноопераційного й оцінно-результативного компонентів готовності майбутніх учителів іноземних мов до формування комунікативної компетенції учнів основної школи на різних етапах експериментального навчання.

Ключові слова: програма і методика експериментального дослідження, динаміка рівнів готовності, професійна підготовка майбутніх учителів іноземних мов.

Дуброва С. В. Профессиональная подготовка будущих учителей иностранных языков к формированию коммуникативной компетенции учащихся основной школы: программа, методика и результаты экспериментального исследования.

В статье раскрыта цель, суть, программа и методика экспериментального исследования, представлены его результаты - динамика и уровни развития когнитивно-операционного и оценочно-результативного компонентов готовности будущих учителей иностранных языков к формированию коммуникативной компетенции учащихся основной школы на разных этапах экспериментального обучения.

Ключевые слова: программа и методика экспериментального исследования, 
динамика уровней готовности, профессиональная подготовка будущих учителей иностранных языков.

Dudrova S. V. Professional preparation of the future foreign language teachers to forming communicative competence in secondary school pupils: program, methodology and results of the pilot research.

In the article we presented the aim, content, program, methodology of the pilot research and its results - the dynamics and levels progress of future foreign language teachers' availability for forming communicative competence in secondary school pupils during pilot study.

Key words: the program and methodology of the pilot research, the dynamics and levels progress, professional future foreign language teachers' preparation.

Освітня система України перебуває в режимі реорганізації та модернізації, зумовленої входженням країни до Болонського процесу. Тому актуальною проблемою сьогодення є створення та впровадження в навчальний процес вищих навчальних закладів нових ефективних технологій підготовки майбутніх учителів іноземних мов.

Питання, пов'язані 3 професійною підготовкою вчителів іноземних мов, висвітлюються в багатьох сучасних роботах, зокрема у працях Ю. Пассова, В. Плахотника, Т. Швець, О. Бігич, С. Ніколаєвої, Н. Скляренко, О. Тарнопольського та інших дослідників.

Проте, зважаючи на значний науковий доробок учених, ми хочемо долучитися до окресленої проблеми і посприяти підвищенню рівня готовності студентів філологічних факультетів, шляхом упровадження у навчальний процес авторської моделі професійної підготовки майбутніх учителів іноземних мов до формування комунікативної компетенції учнів основної школи.

Mema cmammi полягає в розкритті та висвітленні програми, методики та результатів експериментального дослідження готовності студентів до формування визначеної компетенції.

Перевірка ефективності розробленої моделі здійснювалася у ході експерименту, беручи до уваги те, що «педагогічний експеримент - комплексний багатокомпонентний метод дослідження, призначений для об'єктивної та доказової перевірки імовірності гіпотези, теоретичних конструкцій, уточнення окремих висновків наукової теорії, який $\epsilon$ ієрархічно організованим i контрольованим процесом науково-педагогічної діяльності» [2, с. 28]. Педагогічний експеримент створює умови задля:

1) перевірки ефективності запроваджень у навчально-виховний процес;

2) порівняння ролі та впливу різних чинників на педагогічний процес;

3) вибору оптимальних чинників для організації певних ситуацій навчання та виховання;

4) виявлення умов реалізації певних педагогічних задач;

5) виявлення специфіки та закономірностей перебігу педагогічного процесу в конкретних, в тому числі й заданих, умовах [1, с. 26].

Суть нашого експериментального дослідження полягає у:

1) вивченні моделі навчального процесу в цілому (структури діяльності його суб'єктів, взаємозв'язку його елементів, структури начального процесу), залежності його результативності, від умов, у яких він выдбувається та ін.;

2) теоретичному обгрунтуванні та розробленні моделі професійної підготовки майбутніх учителів іноземних мов, що спрямована на удосконалення навчального 
процесу;

3) спеціальній організації навчальної діяльності суб'єктів навчального процесу для перевірки ефективності упроваджуваних змін, створення відповідних педагогічних умов;

4) фіксуванні та виявленні реальних результатів в умовах експерименту.

Метою нашого дослідження стало - теоретичне обгрунтування, розроблення та експериментальна перевірка моделі професійної підготовки майбутніх учителів іноземних мов до формування комунікативної компетенції учнів основної школи, розроблено програму експериментальної перевірки ефективності моделі.

Програма експериментальної перевірки передбачає кілька етапів, для кожного 3 яких визначено завдання діяльності (див. табл. 1).

Програма експериментального дослідження

Таблиия 1

\begin{tabular}{|c|c|c|}
\hline $\begin{array}{c}\text { Назви етапів } \\
\text { експерименталь-ного } \\
\text { дослідження }\end{array}$ & $\begin{array}{c}\text { Додаткові блоки } \\
\text { експериментального } \\
\text { дослідження }\end{array}$ & $\begin{array}{c}\text { Завдання } \\
\text { експериментального } \\
\text { дослідження }\end{array}$ \\
\hline 1. Підготовчий етап & & 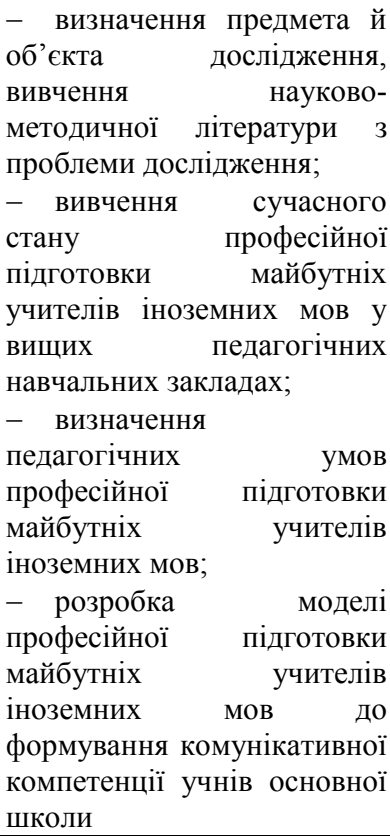 \\
\hline 2. Дослідницький етап & 2.1.Констатувальний етап & $\begin{array}{l}\text { - створення } \\
\text { мотиваційного, } \\
\text { методичного } \\
\text { організаційного } \\
\text { забезпечення експерименту; } \\
\text { - виділення } \\
\text { експериментальних } \\
\text { контрольних груп студентів } \\
\text { та встановлення фактичного }\end{array}$ \\
\hline
\end{tabular}




\begin{tabular}{|c|c|c|}
\hline $\begin{array}{c}\text { Назви етапів } \\
\text { експерименталь-ного } \\
\text { дослідження } \\
\end{array}$ & $\begin{array}{c}\text { Додаткові блоки } \\
\text { експериментального } \\
\text { дослідження } \\
\end{array}$ & $\begin{array}{c}\text { Завдання } \\
\text { експериментального } \\
\text { дослідження } \\
\end{array}$ \\
\hline & & $\begin{array}{l}\text { рівня їх готовності до } \\
\text { формування комунікативної } \\
\text { компетенції учнів основної } \\
\text { школи }\end{array}$ \\
\hline & \multirow{2}{*}{ 2.2.Формувальний етап } & $\begin{array}{lr}-\quad \text { упровадження } \\
\text { розробленої } \\
\text { професійної } \\
\text { майбутніх } & \text { поделі } \\
\text { підготовки } \\
\text { учителів }\end{array}$ \\
\hline & & $\begin{array}{l}\text { іноземних } 1 \text { мов } \\
\text { формування комунікативної } \\
\text { компетенції учнів основної } \\
\text { школи }\end{array}$ \\
\hline 3. Оброблення даних & & $\begin{array}{lcr}\text { - } & \text { використання } & \text { методів } \\
\text { аналізу та } & \text { математичної } \\
\text { обробки } & \text { результатів } \\
\text { дослідження } & 3 & \text { метою } \\
\text { узагальнення, зведення в } \\
\text { систему показників, що } \\
\text { отримані } & \text { в } \\
\text { констатувального ході } \\
\text { формувального } \\
\text { експерименту } \\
\end{array}$ \\
\hline $\begin{array}{l}\text { 4. Інтерпретація даних та } \\
\text { формування висновків }\end{array}$ & & $\begin{array}{l}\text { - обгрунтування } \\
\text { отриманих результатів та } \\
\text { формулювання висновків } \\
\text { щодо підтвердження чи } \\
\text { спростування ефективності } \\
\text { розробленої моделі }\end{array}$ \\
\hline $\begin{array}{l}\text { 5. Впровадження } \\
\text { результатів } \\
\text { експерименту }\end{array}$ & & $\begin{array}{lr}\text { - } \text { упровадження } & \text { в } \\
\text { практику } & \text { професійної } \\
\text { підготовки } & \text { вищих } \\
\text { навчальних } & \text { закладів } \\
\text { змістового } & \text { модуля } \\
\text { навчальної } & \text { дисципліни } \\
\text { «Методика } & \text { викладання } \\
\text { іноземних } & \text { мов в ЗОШ» } \\
\text { щодо } & \text { професійної } \\
\text { підготовки } & \text { майбутніх } \\
\text { учителів іноземних мов до } \\
\text { формування комунікативної } \\
\text { компетенції учнів основної } \\
\text { школи }\end{array}$ \\
\hline
\end{tabular}


Апробація експерименту здійснювалася впродовж 2013-2014 навчального року, в експерименті взяло участь 178 студентів 3 курсу філологічного факультету ДВНЗ «Переяслав-Хмельницький ДПУ імені Григорія Сковороди», Навчально-наукового інституту іноземних мов Черкаського національного університету імені Богдана Хмельницького, Інституту іноземної філології Національного педагогічного університету імені М. П. Драгоманова. У кожному навчальному закладі було виділено експериментальну (ЕГ) і контрольну (КГ) групи, для перевірки ефективності розробленої моделі професійної підготовки майбутніх учителів іноземних мов до формування комунікативної компетенції учнів основної школи.

На констатувальному етапі було визначено фактичний рівень готовності студентів до формування комунікативної компетенції учнів основної школи в обох групах. Загальна структура готовності містить такі компоненти:

1) ціле-мотиваційний - ціннісні орієнтації, мотиви, ставлення студентів до навчання та майбутньої професійної діяльності;

2) когнітивно-операційний - професійні знання та вміння, необхідні для формування комунікативної компетенції учнів основної школи;

3) оцінно-результативний - уміння визначати рівень досягнутих результатів навчання та об'єктивно їх оцінювати.

Рівень сформованості когнітивно-операційного та оцінно-результативного компонентів було встановлено відповідно до розроблених критеріїв $\mathrm{i}$ показників. Діагностування компонентів готовності проводилася за допомогою власних розроблених методик та методики діагностики спрямованості особистості Б. Басса, адаптованої відповідно до завдань нашого дослідження. Методичну базу дослідження представлено в таблиці 2.

Таблиия 2

Методична база дослідження готовності майбутніх учителів іноземних мов до формування комунікативної компетенції учнів основної школи

\begin{tabular}{|c|c|c|c|}
\hline $\begin{array}{c}\text { Компоненти } \\
\text { готовності }\end{array}$ & $\begin{array}{l}\text { Зміст компоненту } \\
\text { готовності }\end{array}$ & $\begin{array}{l}\text { Критерії } \\
\text { готовності }\end{array}$ & Методики дослідження \\
\hline $\begin{array}{c}\text { Ціле- } \\
\text { мотиваційний }\end{array}$ & $\begin{array}{l}\text { особистісна } \\
\text { спрямованість } \\
\text { майбутніх учителів } \\
\text { іноземних мов на } \\
\text { оволодіння } \\
\text { компетенціями, } \\
\text { усвідомлення мети і } \\
\text { завдання підготовки }\end{array}$ & & $\begin{array}{l}\text { модифікований варіант } \\
\text { методики } \\
\text { діагностування } \\
\text { спрямованості } \\
\text { особистості } \\
\text { Б. Басс); } \\
\text { анкета для визначення } \\
\text { ставлення студентів до } \\
\text { навчання та майбутньої } \\
\text { професійної діяльності }\end{array}$ \\
\hline
\end{tabular}




\begin{tabular}{|c|c|c|c|}
\hline $\begin{array}{l}\text { Когнітивно- } \\
\text { операційний }\end{array}$ & 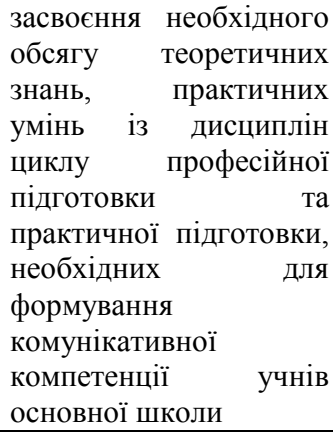 & $\begin{array}{l}\text { змістовий та } \\
\text { операційний } \\
\text { критерії }\end{array}$ & 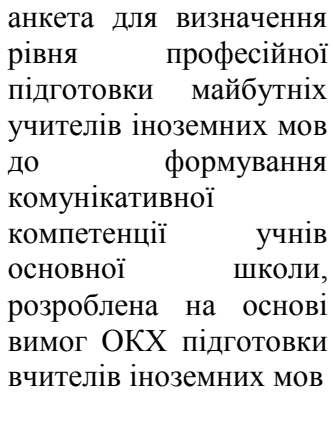 \\
\hline $\begin{array}{c}\text { Оцінно- } \\
\text { результативний } \\
\text { (самоконтроль, } \\
\text { самооцінка) }\end{array}$ & $\begin{array}{l}\text { оцінка викладача і } \\
\text { самооцінка майбутніх } \\
\text { учителів іноземних мов } \\
\text { досягнутих у процесі } \\
\text { навчання результатів }\end{array}$ & & \\
\hline
\end{tabular}

У результаті дослідження сформованості ціле-мотиваційного компоненту готовності було виявлено, що 65,2 \% студентів ЕГ та 64 \% респондентів КГ позитивно ставляться до навчання і майбутньої професійної діяльності, 25,8 \% ЕГ та 28,1 \% опитуваних КГ - посередньо і лише 9 \% студентів ЕГ та 7,9 \% КГ - негативно.

Наступними важливими компонентами готовності, рівень сформованості яких ми досліджували в ході констатувального етапу експерименту, $є$ когнітивноопераційний та оцінно-результативний. Компоненти розглядалися у контексті аналізу цілісної системи знань і вмінь, отриманих у процесі навчання у педагогічному ВНЗ і необхідних задля здійснення професійної діяльності на високому рівні.

Студентам було запропоновано оцінити рівень сформованості когнітивноопераційного та оцінно-результативного компонентів готовності за 5 бальною шкалою, де 5 - високий, 3 - середній, 1 - низький рівень володіння знаннями та вміннями, необхідними для формування комунікативної компетенції учнів основної школи.

Оброблення результатів анкетування здійснювалася відповідно до методики відносних частот О. Смірнова [3, с. 117-121]. Задля порівняльного аналізу за кожним із параметрів анкети підраховувалася відносна частота вияву параметра за такою формулою:

$$
\omega=\frac{\sum_{i=1}^{n} x_{i}}{5 \times n}
$$

де $\omega$ - відносна частота вияву параметра; $\mathscr{n}$ - кількість студентів; $\mathscr{L}_{\mathfrak{L}}-$ оцінка $\hat{i}$-им студентом параметра; $\sum_{i=1}^{n} x_{i}$ - отримана сумарна кількість балів; $5 \times n-$ максимально можлива кількість балів для вибраного параметра.

У ході констатувального етапу експерименту виявлено нерівномірність формування у майбутніх учителів іноземних мов визначених груп знань та вмінь, меншою мірою сформовані на достатньому рівні, в більшій у студентів середнього i високого рівня навчальних досягнень.

На основі аналізу отриманих результатів з'ясовано, що найкраще студенти 
володіють знаннями $з$ базових психолого-педагогічних дисциплін (КГ - 0,82, ЕК $0,81)$, оскільки вони вже засвоїли ці знання в ході навчання. Нижчі показники сформованості мають професійні знання (КГ - 0,53, КГ - 0,54) та професійні вміння (КГ - 0,51, ЕГ- 0,52), це пов'язано з тим, що майбутні вчителі іноземних мов продовжують опановувати дисципліни циклу професійної підготовки.

Із визначених груп умінь низькі показники отримали гностичні (КГ - 0,52, ЕГ 0,53) конструктивно-проектувальні (КГ - 0,51, ЕГ- 0,52) та оцінно-результативні (КГ - 0,51, ЕГ- 0,52), більш високі- організаторські (КГ- 0,63, ЕГ- 0,62) та комунікативні (КГ - 0,66, ЕГ - 0,65).

Слід зазначити, що певний рівень сформованості зазначених груп знань та вмінь пояснюється їх взаємозалежністю, оскільки одні є основою оволодіння іншими, та неоднозначним співвідношенням теоретичної $\mathrm{i}$ практичної частини програм підготовки майбутніх учителів іноземних мов, оскільки у процесі такої підготовки студенти засвоюють теоретичний складник навчального матеріалу та опановують уміння практично іiі реалізовувати, тому процес навчання має бути оптимально організованим задля досягнення якісних результатів.

Упровадження розробленої моделі здійснювалося на формувальному етапі експериментального дослідження. У навчальний процес педагогічних ВНЗ, для засвоєння, конкретизації, систематизації, поглиблення професійних знань та вмінь студентів ЕГ, було внесено авторський курс «Формування комунікативної компетенції учнів основної школи. Аудіювання, говоріння, читання, письмо».

Зазначимо, що у ході та після формувального етапу проводилося діагностування рівнів оволодіння студентами КГ та ЕГ визначеними групами знань та вмінь, задля простеження динаміки змін, надано порівняльну характеристику результатів формування когнітивно-операційного та оцінно-результативного компонентів готовності КГ і ЕГ груп представлено в таблиці 3.

Таблиия 3

Результати дослідження

когнітивно-операційного та оцінно-результативного компонентів готовності до формування комунікативної компетенції учнів основної школи (у відносних частотах)

\begin{tabular}{|c|c|c|c|c|c|c|c|c|}
\hline \multirow[b]{2}{*}{$\begin{array}{c}\text { № } \\
\text { ח/п }\end{array}$} & \multirow[b]{2}{*}{ Знання та вміння } & \multicolumn{3}{|c|}{ КГ } & \multicolumn{3}{|c|}{$\mathrm{E} \Gamma$} & \multirow[b]{2}{*}{ 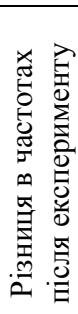 } \\
\hline & & 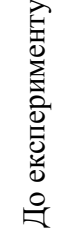 & 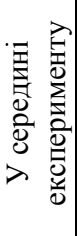 & 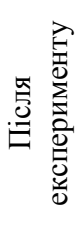 & 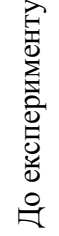 & 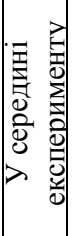 & 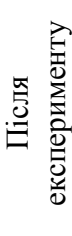 & \\
\hline 1. & Психолого-педагогічні знання & 0,82 & 0,82 & 0,82 & 0,81 & 0,86 & 0,93 & 0,11 \\
\hline 2. & Професійні знання & 0,53 & 0,63 & 0,72 & $\overline{0,54}$ & 0,71 & 0,91 & 0,19 \\
\hline 3. & Професійні вміння & 0,51 & 0,60 & 0,69 & 0,52 & 0,70 & 0,89 & 0,20 \\
\hline 4. & Гностичні вміння & 0,52 & 0,68 & 0,73 & $\overline{0,53}$ & 0,73 & 0,89 & 0,16 \\
\hline 5. & Конструктивно-проектувальні вміння & 0,51 & 0,66 & 0,71 & 0,52 & 0,75 & 0,88 & 0,17 \\
\hline 6. & Організаторські вміння & 0,63 & 0,67 & 0,73 & 0,62 & 0,72 & 0,91 & 0,18 \\
\hline 7. & Комунікативні вміння & 0,66 & 0,69 & 0,75 & 0,65 & 0,76 & 0,92 & 0,17 \\
\hline 8. & Оцінно-результативні вміння & 0,51 & 0,62 & 0,71 & 0,52 & 0,68 & 0,89 & 0,18 \\
\hline
\end{tabular}


Достовірність отриманих результатів констатувального та формувального етапів експерименту забезпечувалася шляхом застосування методів математичної статистики методики відносних частот О. Смірнова та статистичного t-критерію розподілу Стьюдента. Перевірка результатів за допомогою зазначених методів підтвердила ефективність впровадження у навчальний процес ВНЗ розробленої моделі професійної підготовки майбутніх учителів іноземних мов до формування комунікативної компетенції учнів основної школи.

Отримані результати експериментального дослідження дають підстави стверджувати, що підвищення рівня підготовки майбутніх учителів іноземних мов відбувалося за умов забезпечення комунікативного спрямування навчального процесу на засадах особистісного й індивідуального підходів до навчання, якісного відбору, структурування й оновлення змісту дисципліни циклу професійної підготовки, застосування інноваційних технологій та педагогічного діагностування, засобів, методів i форм, передбачених моделлю, впровадження авторського курсу «Формування комунікативної компетенції учнів основної школи. Аудіювання, говоріння, читання, письмо» у процесі формувального етапу експерименту.

\section{Література}

1. Жосан О. Е. Педагогічний експеримент : [навчально-методичний посібник] / О. Е. Жосан. - Кіровоград : Видавництво КОІППО імені Василя Сухомлинського, 2008. - 72 с. 2. Панасенко Е. А. Зміст і структура експерименту як методу наукового дослідження у теорії та практиці вітчизняної педагогіки (1945-1991рр.)/ Е. А. Панасенко // Рідна школа. - 2011. - № 11. - С. 28-33. 3. Смирнов А. В. Статистическая обработка анкет содержащих бальные шкалы/ А. В.Смирнов, Р. А. Смирнова // Резервы интенсификации учебно-воспитательного процесса педвуза: [межвуз. сб. науч. труд.] / [под общ. ред. С. Т. Никифоровой]. - Кострома : [б. и.], 1990.C. $117-121$.

\section{К ВОПРОСУ О ФОРМИРОВАНИИ ПЕДАГОГИЧЕСКИХ ТЕХНОЛОГИЙ ПОДГОТОВКИ СОЦИАЛЬНОГО РАБОТНИКА КАК СУБЪЕКТА СОЦИАЛЬНО-ПОМОГАЮЩЕЙ ДЕЯТЕЛЬНОСТИ}

Зритнєва О. І., Конигіна А. В. До питання про формування педагогічних технологій підготовки соціального робітника як суб'єкта соціально-допоміжної діяльності.

Авторами розглянуто процес технологізації соціальної роботи як соціальнодопоміжної діяльності, яка передбачає формування соціальних технологій науковопрактичного та навчального ії видів, які розвиваються безпосередньо в соціальній галузі і спрямовані на зміни соціальної ситуації в ній. У статті розкрито специфіку соціальних технологій різниї форм і видів соціально-допоміжної діяльності, яка визначає орієнтири побудови системи підготовки сучасних професіоналів соціальної галузі, розробки системи педагогічних технологій освітнього процесу соціального робітника як суб'єкта соціально-допоміжної діяльності.

Ключові слова: технологізація, соціально-допоміжна діяльність, соціальна робота, соціальні технології, педагогічні технології.

Зритнева Е. И., Коныгина А. В. К вопросу о формировании педагогических технологий подготовки социального работника как субъекта социально-помогающей 